\title{
PHYTOCHEMICALS DETECTION, ANTIOXIDANT AND ANTIMICROBIAL ACTIVITY STUDY ON BERRIES OF SOLANUM TORVUM
}

\author{
IDA CHRISTI VE*, UMA POORANI T, NAGARAJAPERUMAL G, MOHAN S
}

Department of Pharmacognosy, Karpagam College of Pharmacy, Coimbatore, Tamil Nadu, India. Email: 1969idacsha@gmail.com

Received: 30 July 2018, Revised and Accepted: 19 September 2018

ABSTRACT

Objective: This present study is planned to reveal about the pharmacognostical details, phytochemistry, antimicrobial activity, and antioxidant activity of aqueous and alcoholic extract of the berries of Solanum torvum Swartz. belonging to the family Solanaceae, which is a very good anti-inflammatory medicine in traditional system of therapies.

Methods: The physicochemical parameters such as ash values, extractive values, and total fiber content, qualitative preliminary phytochemical studies, quantitative estimation for total phenolic contents and flavonoid content, anjd inorganic minerals such as sodium, calcium, and potassium were estimated. Flavonoids present in the methanolic extract were isolated and its $\mathrm{R}_{\mathrm{f}}$ values were calculated by high-performance thin-layer chromatography method and compared with that of the standard epicatechin. The antioxidant activity was evaluated by Reducing power ability, 1, 1-diphenyl-2-picrylhydrazyl method, and hydrogen peroxide methods. The antibacterial and antifungal activities of the aqueous and methanolic extracts are evaluated by disc diffusion method comparing the zone of inhibition with that of the standards such as amikacin and Ketoconazole.

Results: It contains a number of potentially pharmacologically active chemicals including the sapogenin steroid, chlorogenin, alkaloids, flavonoids, phenols, and tannins. Both the extracts showed good activity, but the alcohol extract is more active toward all bacterial organisms and also toward fungi organism. Methanol extract shows good antioxidant activity. Antimicrobial activity and antioxidant activity of the berries are due to the presence of phytoconstituents present in it.

Conclusion: These berries can be used for new formulation in nutraceuticals and polyherbal natural formulations for reducing the oxidative stressrelated diseases and different therapies.

Key words: Solanum torvum Swartz, Epicatechin, Pharmacognosy, Anti-inflammatory, Nutraceuticals.

(C) 2018 The Authors. Published by Innovare Academic Sciences Pvt Ltd. This is an open access article under the CC BY license (http://creativecommons. org/licenses/by/4. 0/) DOI: http://dx.doi.org/10.22159/ajpcr.2018.v11i11.28752

\section{INTRODUCTION}

Solanum torvum Swartz (Turkey Berry) is also known as devil's fig, prickly nightshade, shoo-shoo bush, wild eggplant, and pea eggplant. It is a bushy, spiny erect, and perennial plant belonging to the family Solanaceae. The berries grow in clusters of tiny green spheres which look like green peas when fully ripen, it becomes yellow to brown [1]. They are thin fleshed and contain numerous flat, round, brown seeds. They hang on the tree in cluster forms and are useful to yield many health benefits either in fresh or dried form [2]. Due to its rapid spread as a weed in disturbed lands, it is difficult to tell which populations are native and which are introduced. In Jamaica, this berry is called susumba or gully beans and is usually cooked in a dish. It is believed to be full of iron and is consumed when one is low in iron. It is a very good anti-inflammatory medicine in Ayurvedic medicine [3]. The berries are soaked in buttermilk for around a week and dried under the sun for $>2$ weeks to get completely dried berries. These dried turkey berries are used in culinary preparations and also in homemade remedies [4]. As an Ayurvedic herb, this plant is used in many ayurvedic treatments, it has sedative, diuretic, and digestive properties also used in the treatment for coughs [5]. It is an excellent tonic for the liver. In India, dried leaf powder is used as medicine for diabetic patient [6]. The leaf juice is used to reduce body heat and unripe fruits are used to strengthen the immunity of the body [7]. In Central America and India the leaf paste is used to apply on cuts and wounds because its fruit and leaves have anti microbial activities to control a range of microbial [8]. In Sierra Leone, the fruit decoction is used to treat children as a cough medicine, whereas in Senegal, the whole plant is taken to treat sore throat and stomach ache [9]. It contains a number of potentially pharmacologically active chemicals including the sapogenin steroid, and chlorogenin [10-13]. The glycoalkaloid solasodine [14-16] is found in its leaves and fruits which is used in India for the manufacture of steroidal sex hormones like oral contraceptives [17]. Natural Antioxidants are the substance that are present naturaly, if it present in low concentrations also compared to those of an oxidisable substrate significantly delays or prevents oxidation of that substance. A lot of natural antioxidants is available, but some antioxidants are manufactured synthetically at present and mixed with food products also. The synthetic antioxidants when taken in vivo lead with a lot of side effects. Generation of free radicals or reactive oxygen species (ROS) during metabolism and some other activities beyond the antioxidant capacity of the biological system gives rise to oxidative stress. This stress may leads to heart diseases, neurodegenerative diseases, cancer development of chronic and agerelated degenerative diseases [18]. The dietary antioxidants oppose this and lower the risk of disease. When antioxidants are added in foods they prevent or delay oxidation of food, by initiating the free radicals formation during their exposure to environmental factors such as air, light and temperature [19]. When they are taken as a food, it lowers the risk related to stress diseases.

\section{METHODS}

Chemicals

Solvents and all the reagents used are analytical grade, such as 1, 1-diphenyl-2-picrylhydrazyl (DPPH) and ascorbic acid which were purchased from Sigma-Aldrich, India. Hydrogen peroxide, trichloroacetic acid, ferric chloride, potassium dihydrogen phosphate, sodium hydroxide, and potassium ferricyanide were purchased from Merck, Mumbai, India. 


\section{Plant materials}

S. torvum Swartz fruits (berries) were collected in Coimbatore district, Tamil Nadu, and authenticated by Dr. G.V.S. Moorthy, Botanical Survey of India, Coimbatore. Its voucher number is BSI/SRC/5/23/2012-13/ Tech.747. The voucher specimen has been submitted and preserved in herbarium for future reference. The fruit was separated from the stem, cleaned and shade dried, then powdered and passed through mesh size 80 , and stored in an airtight container.

\section{Preparation of extract}

Weighed about $1 \mathrm{~kg}$ of powdered drug and extracted with methanol and water separately by cold maceration method for 7 days. Then, the extracts were filtered and the last traces of the solvent were evaporated under reduced pressure in a rotary evaporator. The yield of the dry extracts was calculated $[20,21]$.

\section{Determination of ash values}

Accurately weighed about $2 \mathrm{~g}$ powdered drug was incinerated in a silica crucible at a temperature not exceeding $450^{\circ} \mathrm{C}$ for $4 \mathrm{~h}$ in a muffle furnace until free from carbon. It was then cooled and weighed. The $\% \mathrm{w} / \mathrm{w}$ of ash with reference to the air-dried drug was calculated. The acid-insoluble ash, water-soluble ash, and sulfated ash were done according to the standard procedure. Average of the triplicate values was calculated $[20,21]$.

\section{Determination of extractive value}

Accurately weighed about $5 \mathrm{~g}$ of air-dried powdered drug was macerated with $100 \mathrm{ml}$ of $90 \%$ alcohol in a closed flask for $24 \mathrm{~h}$, shaken frequently during first $6 \mathrm{~h}$, and allowed to stand for $18 \mathrm{~h}$. It was then filtered rapidly, taking precautions against loss of the solvent, and $25 \mathrm{ml}$ of the filtrate was evaporated to dryness in a tared flat-bottomed shallow dish and dried at $100^{\circ} \mathrm{C}$ to get constant weight. The $\% \mathrm{w} / \mathrm{w}$ of alcoholsoluble extractive value was calculated with reference to the air-dried drug. The same procedure was repeated with different solvents such as chloroform, petroleum ether, benzene, and water according to the standard procedure $[20,21]$.

\section{Determination of fiber content}

About $3 \mathrm{~g}$ of the powdered drug was weighed and extracted with petroleum ether at room temperature. Then, the drug was dried from that $2 \mathrm{~g}$ of drug was taken for the estimation. The drugs were boiled separately with $300 \mathrm{ml}$ of dilute sulfuric acid for $30 \mathrm{~min}$. Filter the extract material through a muslin cloth and wash with boiling water. Then, boil the material with $200 \mathrm{ml}$ dilute sodium hydroxide for $30 \mathrm{~min}$. Filter through muslin cloth and wash with boiled water $25 \mathrm{ml}$ of alcohol successively. After washing the residue, transfer to silica crucible, which was previously weighed (W1). Dry the residue for $2-3 \mathrm{~h}$ for $130^{\circ} \mathrm{C}$ and cool the crucible in the desiccators and weigh again (W2). Incinerate the residue for $30 \mathrm{~min}$ at $100^{\circ} \mathrm{C}$ and cool it to room temperature in desiccators and weigh again (W3). Then, the total fiber content was calculated using the following formula: (W2-W1) - (W3-W1)/weight of sample×100 [20,21].

\section{Preliminary phytochemical analysis}

The methanol and water extracts were prepared and taken for the preliminary photochemical evaluation by standard procedure used to detect the nature of phytoconstituents present in the fruits of S. torvum $[20,21]$.

\section{Estimation of total phenols}

The total phenol content was determined according to the following method [22]. $10 \mu$ litter aliquots of the extracts $(2 \mathrm{mg} / 2 \mathrm{ml})$ were taken in test tubes and made up to the volume of $1 \mathrm{ml}$ with distilled water. Then, $0.5 \mathrm{ml}$ of Folin-Ciocalteu phenol reagent (1:1 with water) and $2.5 \mathrm{ml}$ of sodium carbonate solution $(20 \%)$ were added sequentially in each tube. Soon after vortexing the reaction mixture, the test tubes were placed in the dark for $40 \mathrm{~min}$ and the absorbance was recorded at $725 \mathrm{~nm}$ against the reagent blank. The analysis was performed in triplicate, and the results were expressed as tannic acid equivalents. Values are means of three independent analyses \pm standard deviation $(n=3)$.

\section{Estimation of total lipid content}

Estimation of total lipid content was determined by the following method $[23,24]$. About $10 \mathrm{~g}$ of the samples were used to extract lipids with $150 \mathrm{ml}$ of petroleum ether for $16 \mathrm{~h}$, at a solvent condensation rate of 2-3 drops/s according to AACC Approved Method 30-25 with minor modifications of sample size and extraction time. The extract obtained was concentrated and evaporated at room temperature to dryness. The weight of extract calculated is the total lipid content and expressed as $\mathrm{mg} / \mathrm{g}$ dry matter.

\section{Estimation of total flavonoids}

The flavonoid content was determined by the use of a slightly modified colorimetric method described previously by this method [25]. A $0.5 \mathrm{ml}$ aliquot of appropriately $(2 \mathrm{mg} / 2 \mathrm{ml}$ ) diluted sample solution was mixed with $2 \mathrm{ml}$ of distilled water and subsequently with $0.15 \mathrm{ml}$ of $5 \% \mathrm{NaNO}_{2}$ solution. After $6 \mathrm{~min}, 0.15 \mathrm{ml}$ of $10 \% \mathrm{AlCl}_{3}$ solution was added and allowed to stand for $6 \mathrm{~min}$, and then, $2 \mathrm{ml}$ of $4 \% \mathrm{NaOH}$ solution was added to the mixture. Immediately, water was added to bring the final volume to $5 \mathrm{ml}$, and then, the mixture was thoroughly mixed and allowed to stand for another $15 \mathrm{~min}$. Absorbance of the mixture was determined at $510 \mathrm{~nm}$ versus water blank. The analysis was performed in triplicate and the results were expressed as rutin equivalent (RE). Values are means of three independent analyses \pm standard deviation $(n=3)$.

\section{Determination of sodium, potassium, and calcium by flame} photometer

An accurately weighed amount of the ash from the fruits of plant was digested with $5 \mathrm{ml}$ of $10 \% \mathrm{HCl}$ and filtered through Whatman No.4 filter paper. The residue was washed with hot water, cooled, and made to volume. The sample solution was then compared in the flame photometer against standard solutions of $\mathrm{NaCl}, \mathrm{KCl}$, and $\mathrm{CaCO}_{3}$ containing the same amount of $\mathrm{HCl}$. The concentrations of the sodium, potassium, and calcium ions were calculated by extrapolation with graph method [26]

\section{Phytochemical screening and high-performance thin-layer chromatography (HPTLC)}

The methanolic extract was subjected to preliminary phytochemical screening to identify the presence of various phytoconstituents present in the extract. Commercially available pre-coated HPTLC plates of Silica gel 60 F254 (Merck, India) were used for the study. The solutions of the extract were applied on the respective HPTLC plates using Linomat IV applicator. The plate was dried after application. $20 \mu \mathrm{L}$ of methanolic fraction of the extract was spotted in the form of a band and epicatechin as a standard also spotted using Linomat IV Sample Applicator (Camag, Switzerland). TLC pattern was developed using toluene:ethyl acetate:formic acid (9:1:6). Then, the plates were scanned in Camag Scanner at a wavelength of $365 \mathrm{~nm}$. Peak areas and peak heights were recorded, from which the percentage of separated compounds was determined $[27,28]$.

\section{Antioxidant activity}

\section{DPPH radical scavenging activity}

The free radical scavenging activity was measured by the following method [29], the decrease in absorbance of methanolic solution of DPPH. A stock solution of DPPH $(33 \mathrm{mg} / \mathrm{L})$ was prepared in methanol and $5 \mathrm{ml}$ of this stock solution was added to $1 \mathrm{ml}$ of the plant extract solutions at different concentrations $(25,50,75,100,150,200$, and $250 \mu \mathrm{g} / \mathrm{ml}$ ). After $30 \mathrm{~min}$, absorbance was measured at $517 \mathrm{~nm}$ and compared with the standard ascorbic acid $(10-50 \mu \mathrm{g} / \mathrm{ml}) \mathrm{pH} 7.4$. The percentage of DPPH scavenging activity of the plant extracts and the standard was calculated. The percentage extract of inhibition was calculated by the following formula: [1-(Absorbance of sample/ Absorbance of control)] $\times 100[30]$ 


\section{Reducing power determination}

The reducing power of the extracts was determined by the following method [31]. The extract and the standard were prepared in different concentrations like $(50-250 \mathrm{mgm} / \mathrm{ml})$ in methanol. The solutions were mixed with phosphate buffer (PH 6.6) and incubated with $(2.5 \mathrm{ml})$ of potassium ferricyanide solution $(1 \% \mathrm{w} / \mathrm{v})$ at $50^{\circ} \mathrm{C}$ for $20 \mathrm{~min}$. Then, $2.5 \mathrm{ml}$ of trichloroacetic acid was added to the mixture which was then centrifuged for $10 \mathrm{~min}$. The supernatant $(2.5 \mathrm{ml})$ was mixed with distilled water $(2.5 \mathrm{ml})$ and ferric chloride $(0.5 \mathrm{ml})$, and the absorbance was measured at $700 \mathrm{~nm}$. Increased absorbance of the reaction mixture indicates increased reducing power [32].

\section{Scavenging of hydrogen peroxide}

The ability of three extracts to scavenge hydrogen peroxide was determined by a solution of hydrogen peroxide (2 mol/l) which was prepared in phosphate buffer $(\mathrm{pH} 7.4)$. Hydrogen peroxide concentration was determined by spectrophotometrically absorbance at $230 \mathrm{~nm}$. Extracts were prepared at the concentration of 50$250 \mathrm{mgm} / \mathrm{ml}$ and added to the hydrogen peroxide solution $(0.6 \mathrm{ml})$. Blank solution contains phosphate buffer without hydrogen peroxide. For each concentration, a separate blank sample was used for background subtraction [33]. The percentage of inhibition activity was calculated from the formula $[(\mathrm{A} 0-\mathrm{A} 1) / \mathrm{A} 0] \times 100$, where $\mathrm{A} 0$ is the absorbance of the control and A1 is the absorbance of extract/standard.

\section{Statistical analysis}

Values were represented as mean+SD of three parallel measurements, and data were analyzed using t-test.

\section{Antimicrobial activity}

The antimicrobial activity of aqueous and alcohol extracts was determined by disc diffusion method [34]. The test organism used for the screening of antibacterial activity is four Gram-positive bacteria ie., (Staphylococcus aureus, Staphylococcus pyogenes, Bacillus subtilis, and Enterococcus faecalis) and four Gram-negative bacteria ie., (Salmonella typhi, Serratia, Proteus mirabilis, and Pseudomonas aeruginosa) and the test organisms used for the screening of antifungal activity is (Aspergillus niger and Candia albicans). These above-mentioned organisms were identified and procured from Microbiology Department, Karpagam University, Coimbatore. The stock cultures were maintained in nutrient agar slant at $4^{\circ} \mathrm{C}$ and subcultured. Working cultures were prepared by inoculating a loopful of each test microorganism in $3 \mathrm{ml}$ of nutrient broth from nutrient agar slants. Broths were incubated at $37^{\circ} \mathrm{C}$ for $12 \mathrm{~h}$. The suspension was diluted with sterile distilled water to obtain approximately $106 \mathrm{CFU} / \mathrm{ml}[35]$.

\section{Disk diffusion method}

The in vitro antibacterial screening of the crude extracts was carried out by the disc diffusion method (Bauer AW, KIRBET). Disk diffusion method is equally suited to screening of antibiotics or the products of plant evaluation and is highly effective for rapidly growing microorganisms, and the activities of the test compounds are expressed by measuring the diameter of the zone of inhibition [36]. In this method, the compounds are applied to the agar medium using paper disc. This method is semi-quantitative test to find the organism as susceptible, intermediate, or resistant to the test materials as well as bacteriostatic or bactericidal activity of the compound.

The extract was dissolved in millipore water and methanol to produce a concentration of $100 \mu \mathrm{g} / \mathrm{ml}$ and $200 \mu \mathrm{g} / \mathrm{ml}$. The sterile discs were prepared by impregnating in the above different extracts and slightly dried to evaporate the solvent. The disk was completely saturated with the extract and allowed to dry. Mueller-Hinton (MH) agar plates were swabbed with test bacteria, and extract disks with one of the standard positive control disks (amikacin and ketoconazole) as a standard for antibacterial and antifungal respectively were placed on the MH agar plate. DMSO was taken as the negative control. Plates were incubated overnight at $37^{\circ} \mathrm{C}$. The zone of inhibition for the extracts against each organism is recorded in terms of millimeter [37].

\section{RESULTS AND DISCUSSION}

The physiochemical parameters such as extractive values, ash values, and total fiber content of powdered drug sample were calculated with reference to the weight of air-dried powdered drug, and the values are given in Table 1.

\section{Phytochemical analysis}

The preliminary qualitative phytochemical analysis of $S$. torvum fruits extracts showed the presence of majority of the compounds including alkaloids, proteins, tannins, phenolic substance, steroidal glycosides, and flavonoids. It is given in Table 2.

Quantitative phytochemical study

The fruits are extracted and quantitatively estimated for the presence of lipid, flavonoid, and phenols and also minerals such as sodium, potassium, and calcium. The results are documented in Table 3.

\section{HPTLC study on the methanolic extract of the fruits of $S$. torvum}

The HPTLC fingerprint of the alcoholic extract of berries shows 9 peaks, and it was compared with that of the epicatechin as a standard for the presence of flavonoid. It shows a clear peak and $R_{f}$ value as same as that of the standard, and it confirms the presence of flavonoid in this extract. The $R_{f}$ values ware documented and the fingerprint of the HPTLC is shown in Figs. 1 and 2. There are 9 peaks obtained in the alcoholic extract of the fruits. However, only one peak, i.e., the first peak is having $R_{\mathrm{f}}$ value 0.18 and it covers the area $92.94 \%$ which is nearer to that of the standard (epicatechin) Rf value 0.17 which covers the peak area $90.71 \%$.

Table 1: Physicochemical evaluation of S. torvum fruits

\begin{tabular}{lll}
\hline S.NO & Parameters & Values (\%) \\
\hline A & Ash values & \\
1 & Total Ash & 5.27 \\
2 & Acid-insoluble ash & 1.21 \\
3 & Water-soluble ash & 1.78 \\
4 & Sulfated ash & 4.45 \\
B & Extractive values & \\
1 & Petroleum ether & 0.93 \\
2 & Chloroform & 0.42 \\
3 & Methanol & 2.23 \\
4 & Water & 11.16 \\
C & Fiber content & 1.49 \\
\hline
\end{tabular}

S. torvum: Solanum torvum

Table 2: Preliminary phytochemical analysis

\begin{tabular}{llll}
\hline S. No. & Chemical test & Methanol extract & Water extract \\
\hline 1 & Alkaloids & + & + \\
2 & Proteins & + & + \\
3 & Tannins & + & + \\
4 & Phenolic compounds & + & + \\
5 & Steroidal glycosides & + & + \\
6 & Flavonoids & + & + \\
\hline \multicolumn{2}{l}{ S. torvum: Solanum torvum }
\end{tabular}

Table 3: Quantitative phytochemical study

\begin{tabular}{ll}
\hline Chemicals parameters & Concentration \\
\hline Total lipids & $13.00 \pm 0.14(\mathrm{mg} / \mathrm{g}$ dry matter $)$ \\
Total phenols & $2.357 \pm 0.48(\mathrm{mg} \mathrm{TAE} / \mathrm{g}$ extract $)$ \\
Total flavonoids & $1.95 \pm 0.030(\mathrm{mg} \mathrm{RE} / \mathrm{g})$ \\
Sodium & $58 \mathrm{ppm}$ \\
Potassium & $18 \mathrm{ppm}$ \\
Calcium & $34 \mathrm{ppm}$ \\
\hline
\end{tabular}

Values represents the mean \pm SD number of readings in each group $=3$ 
Table 4: Antimicrobial activity of methanol and aqueous extracts of Solanam torvam berries

\begin{tabular}{|c|c|c|c|c|c|c|c|}
\hline \multirow[t]{3}{*}{ S.NO } & \multirow{3}{*}{$\begin{array}{l}\text { Name of the organism } \\
\text { Bacteria }\end{array}$} & \multicolumn{6}{|c|}{ Solanam torvam } \\
\hline & & \multicolumn{3}{|c|}{ Water extract $\mu \mathrm{g} / \mathrm{ml}$} & \multicolumn{3}{|c|}{ Methanol extract $\mu \mathrm{g} / \mathrm{ml}$} \\
\hline & & 100 & 200 & Standard & 100 & 200 & Standard \\
\hline 1 & Staphylococcus aureus (positive) & 12 & 16 & 18 & 9 & 16 & 18 \\
\hline 2 & Streptococcus pyogenes (positive) & 12 & 15 & 17 & 9 & 12 & 17 \\
\hline 3 & Bacillus subtilis (positive) & 14 & 16 & 20 & 10 & 12 & 20 \\
\hline 4 & Enterococcus faecalis (positive) & 12 & 16 & 17 & 10 & 13 & 17 \\
\hline 6 & Serratia (negative) & 9 & 14 & 19 & 10 & 13 & 17 \\
\hline 7 & Pseudomonas aeruginosa (negative) & 9 & 15 & 18 & 6 & 12 & 18 \\
\hline 8 & $\begin{array}{l}\text { Proteus mirabilis (negative) } \\
\text { Fungus }\end{array}$ & 7 & 10 & 18 & 10 & 12 & 18 \\
\hline 9 & Aspergillus flavus & 12 & 17 & 23 & 13 & 18 & 23 \\
\hline 10 & Candida albicans & 13 & 11 & 20 & 12 & 17 & 20 \\
\hline
\end{tabular}

Bacteria standard: Amikacin, fungal standard: ketoconazole

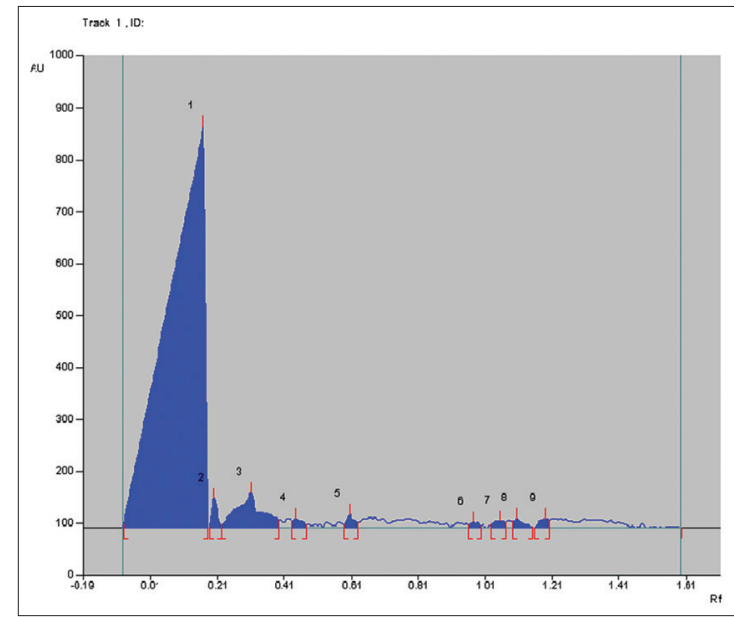

Fig. 1: Standard

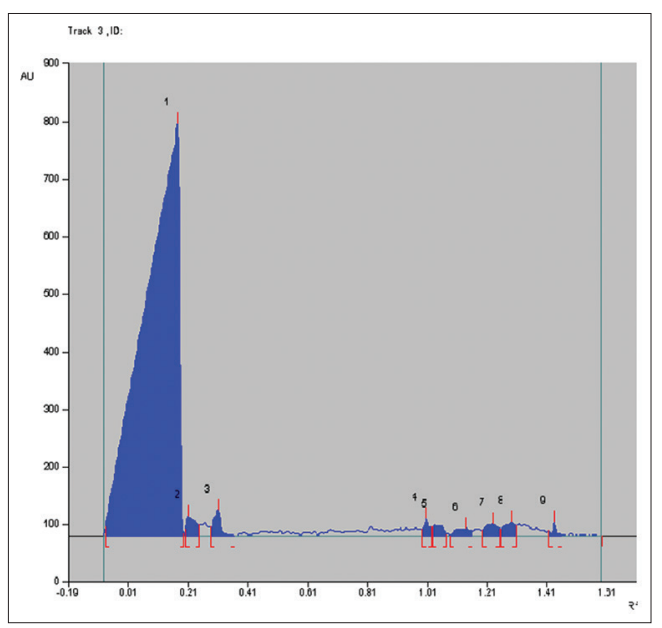

Fig. 2: Sample (extract)

\section{Antioxidant activity}

The free radicals scavenging activity of extract of the fruits of the plants was compared with the positive control ascorbic acid in DPPH free radical scavenging activity method, which shows very good activity, and its $\mathrm{IC}_{50}$ value of $S$. torvum was found to be as $170 \mu \mathrm{g} / \mathrm{ml}$ equivalent to that of $70 \mu \mathrm{g} / \mathrm{ml}$ of ascorbic acid. In the hydrogen peroxide method, the $\mathrm{IC}_{50}$ value of $S$. tarvum was found to be $180 \mu \mathrm{g} / \mathrm{ml}$ equivalent to that of $80 \mu \mathrm{g} / \mathrm{ml}$ ascorbic acid. By the reducing power ability method, the $\mathrm{IC}_{50}$ value of extract was found to be $160 \mu \mathrm{g} / \mathrm{ml}$ of the extract is equivalent to

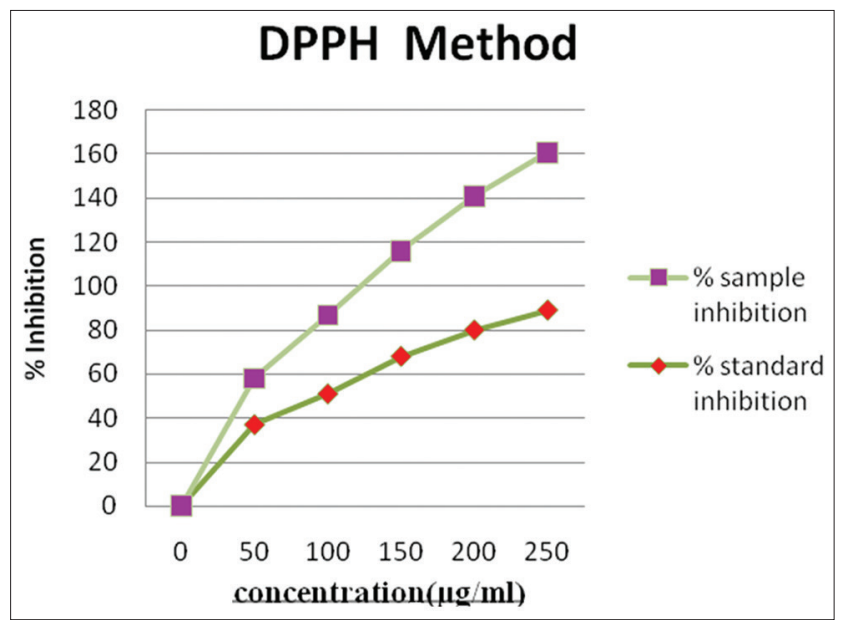

Fig. 3: 1, 1-diphenyl-2-picrylhydrazyl method

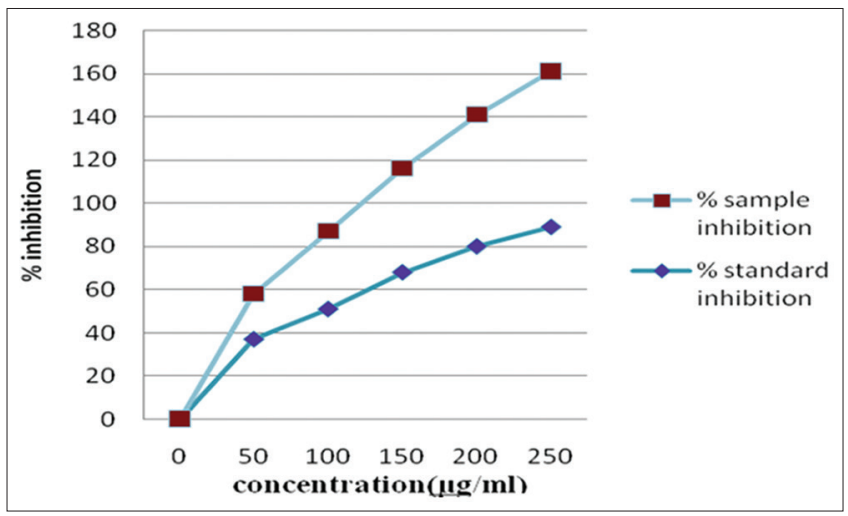

Fig. 4: $\mathrm{H}_{2} \mathrm{O}_{2}$ method

that of $90 \mu \mathrm{g} / \mathrm{ml}$ of epicatechin as a standard. The results are explained in Figs. 3-5.

\section{Antimicrobial activity}

The zone of inhibition for the extracts against different organism is recorded in terms of millimeter and it was documented in Table 4.

\section{DISCUSSION}

Free radicals, mainly the ROS, involved in initiation, promotion, and progression of carcinogenesis. ROS induces oxidative damage of DNA and cellular components leading to cancer-related mutations. 


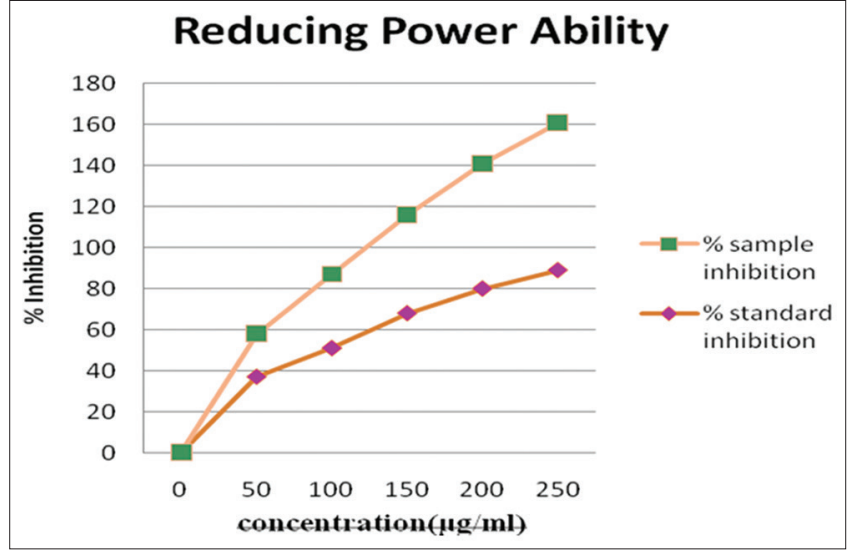

Fig. 5: Reducing power ability

Consequently, antioxidant plays an important role in the protection of the human body, against damage by ROS, and also, the intake of natural antioxidant has been associated with reduced risk of cancer and other diseases related with oxidative damages which is related to the phenolic compound and the phenolic hydroxyl group [19]. The concentration of hydrogen peroxide in water varies according to the phenolic compound [38]. Since phenolic compounds present in the extract are good electron donors, they may accelerate the conversion of $\mathrm{H}_{2} \mathrm{O}_{2} \rightarrow \mathrm{H}_{2} \mathrm{O}$. ROS including free radicals such as superoxide anion radicals, hydroxyl radicals, non-free radicals such as $\mathrm{H}_{2} \mathrm{O}_{2}$, and singlet oxygen along with various forms of active oxygen is involved in various physicochemical processes in the body and aging [39]. Hydrogen peroxide is mainly produced by enzymatic reaction. These enzymes are located in microsomes, peroxisomes, and mitochondria. In plant and animal cells, superoxide dismutase is able to produce hydrogen peroxide by dismutation of oxygen, thus contributing to the lowering of oxidative reactions. The natural combination of dismutase and catalase contributes to remove hydrogen peroxide and thus has a true cellular antioxidant activity. The ability of the plant extracts to scavenge hydrogen peroxide is followed by a decay in hydrogen peroxide concentration. $\mathrm{O}_{2}^{-}+\mathrm{H}_{2} \mathrm{O}_{2} \rightarrow \mathrm{OH}^{-}+\mathrm{OH}^{+}+\mathrm{O}_{2}$. Most of the simple phenols are monomeric compounds of the polymeric polyphenols and acids which make up plant tissues, including lignin, melanin, flavonols, and tannins. These individual components are obtained by acid hydrolysis of tissues. Some flavonoids can chelate divalent metal ions, hence preventing free radical formation.

Apart from their role of health benefactors, antioxidants are added in foods to prevent or delay oxidation of food, initiated by free radicals formed during their exposure to environmental factors such as air, light, and temperature [40]. At present, most of the antioxidants are manufactured synthetically [41]. Plants are the potential source of natural antioxidants. Natural antioxidants or phytochemical antioxidants are the secondary metabolites of plants. Flavonoids are phenolic compounds, present in several plants, which inhibit lipid peroxidation and lipoxygenases in vitro and in the presence of free metal ion $\left(\mathrm{Fe}^{3+}\right)$ [42]. In this present study, three methods, namely hydrogen peroxide method, DPPH radical scavenging method, and reducing power ability method, were used to find and correlate the antioxidant activity of the extracts. The selected berries are having some nutritional valuable minerals. The micronutritients present in the fruits are most important for their antioxidant and antimicrobial activity [43]. Hydrogen peroxide is also able to diffuse easily through cell membrane. The generation of hydrogen peroxide by activated phagocytes is known to play an important part in the killing of several bacterial and fungal strains $[44,45]$. When screening the antibacterial activity, the aqueous extract is showing better activity than the methanol extract when comparing with that of the standard drug Amikacin, and in the antifungal activity, the methanol extract is showing better activity than the aqueous extract when comparing with that of the standard drug ketoconazole. The activity is also dose dependent because it shows better activity when increasing the dose.

\section{CONCLUSION}

From this study, the berries of S. tarvum are having very good antioxidant and antimicrobial activity, which may be due to the presence of phenols and flavonoids in this fruits. This fruit is also having a considerable quantity of sodium, potassium, and calcium. This study also indicates that it can be used as food as well as medicine without side effect. This study will update the pharmacognostical and phytochemical details to go head for new nutraceuticals or new herbal formulations for a lot of health problems in human.

\section{AUTHORS' CONTRIBUTIONS}

This experimental work design and drafting the manuscript correction of the manuscript were done by Ida Christi. The authors are grateful for laboratory facilities provided by Pharmacognosy Department, Karpagam College of Pharmacy.

\section{CONFLICTS OF INTEREST}

There were no conflicts of interest.

\section{REFERENCES}

1. Adjanohoun J, Aboubakar N, Dramane K, Ebot E, Ekpere A, Enoworock G, et al. Traditional Medicine and PharmacopeiaContribution to Ethnobotanical and Floristic Studies in Cameroon. Porto-Novo, Benin: CNPMS; 1996. p. 50-2.

2. Rahmatullah M, Mukn IJ, Haque AK, Molkh MH, Parvin K, Jahan R, et al. An ethnobotanical survey and pharmacological evalution of medicinal plants used by the garo tribal community living in Netrakona district, Bangladesh. Adv Nat Appl Sci 2009;3:402-18.

3. Adjanohoun J, Aboubakar N, Dramane K, Ebot E, Ekpere A, Enoworock G, et al. Traditional Medicine and PharmacopeiaContribution to Ethnobotanical and Floristic Studies in Cameroon. Porto-Novo, Benin: CNPMS; 1996. p. 50-2.

4. Ndebia EJ, Kamga R, Nchunga-Anye NB Analgesic and anti- inflammatory properties of aqueous extract from leaves of Solanum torvum (Solanaceae). AJTCAM 2007;4:240-4.

5. Sivapriya $M$, Srinivas L. Isolation and purification of a novel antioxidant protein from the water extract of Sundakai (Solanum torvum) seeds. Food Chem 2007;104:510-7.

6. Gandhi GR, Ignacimuthu S, Paulraj MG, Sasikumar P. Antihyperglycemic activity and antidiabetic effect of methyl caffeate isolated from Solanum torvum Swartz. Fruit in streptozotocin induced diabetic rats. Eur J Pharm 2011;670:623-31.

7. Ngulefacka TB, Catherine BF, Gilber A, Pierre W, Simplice T, Albert DA, et al. Anti ulcerogenic properties of the aqueous and methanol extracts from the leaves of Solanum torvum Swartz (Solanaceae) in rat. J Complimentary integr Med 2008;5:24-9.

8. Atta A, Alkofahi A. Anti-nocive and anti-inflammatory effects of some Jordanian medicinal plant extracts. J Ethnopharm 1997;60:117-24

9. Ngulefacka TB, Mekhif H, Dongmo AB, Dimo T, Afkir S, Elvin PN, et al. Cardiovascular and anti-platelet aggregatives of extracts from Solanum torvum fruits in rats. J Complementary Integr Med 2008;5:24-9.

10. Ngulefacka TB, Mekhif H, Dongmo AB, Dimo T, Watcho P, Johar Z, et al. Hypertensive effect of oral administration of the aqueous extract of Solanum torvum fruits in rates, evidence from in vivo and in vitro studies. J Ethnopharm 2009;124:592-9.

11. Cuervo C, Blunden G, Patel AV. Chlorogenone and neochlorogenone from the unripe fruits of Solanum torvum. Phytochemistry 1991;30:1339-41.

12. Arthan D, Svasti J, Kittakoop P, Pittayakhachonwut D, Tanticharoen M, Thebtaranonth $\mathrm{Y}$, et al. Antiviral isoflavonoid sulfate and steroidal glycosides from the fruits of Solanum torvum. Phytochemistry 2002;59:459-63.

13. Lu YY, Luo JG, Kong LY, Structure elucidation and complete NMR spectral assignments of new furostanol glycosides from Solanum torvum. Magn Reson Chem 2009;47:808-12.

14. Yahara S, Yamashita T, Nozawa N, Nohara T, Steroidal glycosides from Solanum torvum. Phytochemistry 1996;43:1069-74.

15. Waghulde H, Kamble S, Patankar P, Jaiswal BS, Pattanayak S, Bhagat C, 
et al. Antioxidant activity, phenol and flavonoid contents of seeds of Punica granatum (Punicaceae) and Solanum torvum (Solanaceae). Pharmacologyonline 2011;1:193-202.

16. Arthan D, Svasti J, Kitta P, Antiviral isoflavonoid sulfate and steroidal glycosides from the fruits of Solanum torvum. Phytochemistry 2001;4:459-63.

17. Mahmood U, Agrawal PK, Thakur RS, Torvonin A. A spirostane saponin from Solanum torvum leaves. Phytochemistry 1985;24:2451-7.

18. Amin I, Norazaidah Y, Emmy HK. Antioxidant activity and phenolic content of raw and blanced Amaranthus species. Food Chem 2006;94:47-52.

19. Zima TS, Fialova L, Mestek O, Janebova M, Crkovska J, Malbohan I, et al. Oxidative stress, metabolism of ethanol and alcohol-related diseases. J Biomed Sci 2001;8:59-70.

20. Kokate CK, Purohit AP, Gokhale SB. Practical Pharmacognosy. $5^{\text {th }}$ ed. India: Vallabhprakashan; 2014. p. 593-7.

21. Khadabadi SS, Deore SL, Baviskar BA, Experimental Phytopharmacognosy. India: Nirali Publishers; 2013. p. 1-4, 12.

22. Siddhuraju P, Becker K. Antioxidant properties of various solvent extracts of total phenolic constituents from three different agro climatic origins of drumstick tree (Moringa oleifera Lam.) leaves. J Agric Food Chem 2003;51:2144-55.

23. Chung OK, Pomeranz Y, Jacobs RM, Howard BG, Lipid extraction conditions to differentiate among hard red winter wheat that vary in bread making. J Food Sci 1980;45:1168-74

24. Chung OK, Pomeranz Y, Finney KF. Relation of polar lipid content to mixing requirement and loaf volume potential of hard red winter wheat flour. Cereal Chem 1982:59:14-20.

25. Zhishen J, Mengcheng T, Jianming W. The determination of flavonoid contents in mulberry and their scavenging effects on superoxide radicals. Food Chem 1999;64:555-9.

26. Beckett AH, Stenlake JB, Practical Pharmaceutical Chemistry. $4^{\text {th }}$ ed. Gary Hall: Humanities Press; 1987. P. 347-55.

27. Harborne JJ. Phytochemical Methods: A Guide to Modern Techniques of Plant Analysis. $2^{\text {nd }}$ ed. New York: Chapman and Hall; 1984. p. 85.

28. Brain KR, Turner TD. The Practical Evaluation of Phytopharmaceuticals Thin Layer Chromatography. $2^{\text {nd }}$ ed. Bristol: MRF Ashworth; 1975.

29. Govindan V, Shoba FG. Qualitative and quantitative determination of secondary metabolites and antioxidant potential of Ficus benghalensis linn seed. Int J Pharm Pharm Sci 2015;7:118-24.

30. Duraiswamy B, Singanan M, Varadarajan V. Physicochemical, phytochemicals and antioxidant evaluation of Guazuma ulmifolia Fruit.
Int J Pharm Pharm Sci 2017;10:87-91.

31. Oyaizu. M. Study on products of browning reactions: Antioxidative activities of products of browning reaction prepared from glucosamine. Jpn Nutr 1986;44:307-15.

32. Ruan ZP, Zhang LL, Lin YM. Evaluation of the antioxidant activity of Syzygium cumini leaves. Molecules 2008;13:2545-56.

33. Ruch RJ, Chung SU, Klaunig JE. Spin trapping of superoxideand hydroxyl radicals. Methods Enzymol 1984;105:198-209.

34. Bauer AW, Kirby WM, Tuch M. Antibiotic susceptibility testing by a standardized disc diffusion method. J Am Clin Pathol 1966;45:493-6.

35. Pharmacopoeia of India, Ministry of Health and Family Welfare. Appendix, Government of India, New Delhi; 1996. p. 53-4.

36. Barry A. Producers and theoretical considerations for testing antimicrobial agents in agar media. In: Antibiotic in Laboratory Medicine. $2^{\text {nd }}$ ed. Baltimore. USA: Williams Wilkins; 1986. p. 1-19.

37. Kumar S, Perumal S, Boopathy P, Mukherjee D, Suresh PK. A Comparative microbiological activities of ethanolic extracts of roots and aerial parts of Achyranthes aspera Linn. Anc Sci Life 2003;22:140-6.

38. Shah A, Singh T, Vijayvergia R. In vitro antioxidant properties and total phenolic and flavonoid contents of Rumex vesicaius L. Int J Pharm Pharm Sci 2015;7:81-4.

39. Amin I, Norazaidah Y, Haihida KI. Antioxidant activity and phenolic content of raw and blanced Amaranthus species. Food Chem 2006;94:47-52.

40. Hras AR, Hadolin M, Knez Z, Bauman D. Comparison of antioxidative and synergistic effects of rosemary extract with alpha-tocopherol, ascorbyl palmitate and citric acid in sunflower oil. Food Chem 2000;71:229-33.

41. Chen C, Pearson AM, Gray JI. Effects of synthetic antioxidants (BHA, BHT and PG) on the mutagenicity of IQ-like compounds. Food Chem 1992; 43:177-83

42. Yingming P, Ping L, Hengshan W, Min L. Antioxidant activities of several Chinese medicinal herbs. Food Chem 2004;88:347-50.

43. Tarwadi K, Agte V. Antioxidant and micronutrient potential of common fruits available in the Indian subcontinent. Int J Food Sci Nutr 2007:58:341-9.

44. Thilagavathi G, Rajendrakumar K, Rajendran R. Development of ecofriendly antimicrobial textile finishes using herbs. Indian J Fibre Text Res 2005;30:431-6.

45. Ojala T. Antimicrobial activity of some coumarin containing herbal plants growing in Finland. J Ethnopharm 2000;73:299-305. 